DOI: $10.31393 /$ reports-vnmedical-2021-25(2)-13

UDC: $616.379-008.64: 577.112: 616.61-07-084$

\title{
RELATIONSHIP BETWEEN BIOCHEMICAL PARAMETERS AND GLOMERULAR FILTRATION RATE BY COCKCROFT-GAULT, CKD EPI AND CYSTATIN C IN PATIENTS WITH TYPE 1 DIABETES
}

\section{Kryvoviaz Yu. $O$.}

National Pirogov Memorial Medical University, Vinnytsya (Pyrogov street, 56, Vinnytsya, Ukraine, 21018)

Responsible for correspondence: e-mail: juliak3x@gmail.com

Received: March, 2, 2021; Accepted: April, 17, 2021

Annotation. The aim of research is to study correlations of biochemical parameters with glomerular filtration rate according to Cockcroft-Gault, CKD EPI and cystatin C in patients with type 1 diabetes (T1D). 78 men and 62 women aged 22-26 years with T1D were examined. The control group consisted of 8 almost healthy men and 13 almost healthy women of the same age. The level of microalbuminuria and cystatin $C$ was determined in all patients by enzyme-linked immunosorbent assay. Biochemical evaluation of fasting blood glucose, glucose $2 \mathrm{~h}$ after exercise, mean value of glucose, creatinine, GFR according to Cockcroft-Gault, CKD EPI and GFR according to cystatin C. Correlation analysis between the series of indicators was calculated using Spearman statistics in the license package "Statistica 5.5". In patients with T1D, there is no significant correlation in normoalbuminuria between urinary albumin levels and GFR by Cockcroft-Gault (in women), CKD EPI and cystatin C (in all study groups). No significant correlations were found between urinary albumin levels and GFR by Cockcroft-Gault, CKD EPI and cystatin $C$ in the proteinuria group. The correlation analysis revealed in the general group and in women with proteinuria an association between the average value of blood glucose and low GFR levels by Cockcroft-Gault, CKD EPI (negative medium strength correlation $r=$ from -0.31 to -0.46 ) and elevated creatinine (positive strong correlation $r=0.62$ and $r=0.91$ ), indicating an unfavorable role of hyperglycemia in the development of nephropathy in patients with T1D. Higher correlations of cystatin C with GFR by cystatin $C(r=-1.0)$ than by creatinine with GFR by Cockcroft-Gault ( $r=$ from -0.63 to 0.99$)$ and by CKD EPI $(r=$ from -0.73 to -0.99) were demonstrated. The strength of the correlations increases from GFR by Cockcroft-Gault to GFR by cystatin C. Correlations between creatinine and GFR by Cockcroft-Gault and CKD EPI were characterized by sex differences (greater in women) and an increase in their strength synchronously with an increase in urinary microalbumin. At the same time, there is a consistently high identical value $(r=-1.0)$ of correlations of the level of cystatin C with GFR on cystatin $C$ in all comparison groups. Neither the sex factor nor the degree of albuminuria affected the change in their strength. Only men with microalbuminuria had moderate feedback between creatinine and cystatin $C(r=-0.46)$. In all groups of women, in the general group and in men with normoalbuminuria and proteinuria, the correlations are close to zero, which may indicate the absence of a linear relationship between these indicators. When dividing the sample according to the level of cystatin $C$ between the level of creatinine and the level of cystatin $C$, the following were found: medium feedback $(r=-0.37)$ in the general group with normoalbuminuria and cystatin $C>0.9$; moderate feedback ( $r=-0.37)$ in the general group and in men with proteinuria and cystatin $C<0.9$ strong feedback ( $r=-0.90$ and $r=-0.88$ ). Thus, in the course of correlation analysis it was found: microalbuminuria is not an independent marker of diabetic nephropathy $(D N)$, starting from preclinical and ending with a clinically manifested stage of this complication; for timely and adequate diagnosis of $D N$ it is necessary to measure the level of albumin, creatinine and cystatin $C$, which are independent markers of renal dysfunction; cystatin $C$ gives a more accurate approximation to the actual values of GFR than creatinine; cystatin $C$ is more sensitive in the early stages, and creatinine is a marker of later stages of DN development; hyperglycemia is the main initiating metabolic factor in the development and progression of $D N$.

Keywords: type 1 diabetes, cystatin $C$ level, urinary albumin level, biochemical parameters, glomerular filtration rate according to Cockcroft-Gault, CKD EPI and according to cystatin C, correlations.

\section{Introduction}

The term "clinically silent organ", which occurs in the literature, is largely true for the kidneys. This is due to the fact that for a long time after exposure to hyperglycemia and the onset of diabetic nephropathy (DN) there are no clinical signs and symptoms of this disorder. DN increases the risk of neurological, ophthalmic complications, coronary heart disease and early death in young and middle-aged adult patients and is an established risk factor for cardiovascular disease in the elderly [2, 9].

Since a living organism is a single whole, and the organs function together, the studied indicators that reflect the function of a particular organ must be interdependent. Accordingly, the change of one of the indicators changes the others. General clinical, biochemical analysis of blood and urine obliges the clinician, in addition to a competent and reliable study, to logically explain the correlation between the obtained indicators. But this practice is often not carried out, which leads to inaccurate interpretation of indicators by a doctor. Failure to comply with this condition is often a situation where the analysis without exaggeration is a technical filing in the map of the disease, without their full understanding and use in treatment $[10,11]$.

Thus, the indicators of lipid and carbohydrate metabolism are not considered separately, but necessarily in conjunction with creatinine, cystatin $C$, indicators of the filtration capacity of the glomeruli and albumin in the urine. 
There are no superfluous indicators, the investigated diagnostic panel can confirm assumptions, refute it or lead to possible pathological process [6]. Analyzing the result, it is necessary to first divide the indicators that directly indicate the pathology in the body (significant decrease in glomerular filtration rate, increased levels of cystatin $\mathrm{C}$, albumin in the urine), and the indicators necessary to specify the pathology (increased glucose, cholesterol, creatinine) and accordingly analyze the relationship between them [8].

The aim of the research was to study correlations of biochemical parameters with glomerular filtration rate by Cockcroft-Gault, CKD EPI and cystatin C in patients with type 1 diabetes (T1D).

\section{Materials and methods}

The sample consisted of 78 men and 62 women aged 22-26 years, patients with T1D, who were hospitalized in the therapeutic department № 1 and № 2 of the Vinnytsia Regional Highly Specialized Endocrinology Center. The control group consisted of 8 healthy men and 13 healthy women of the same age.

All patients underwent the procedure of determining the level of microalbuminuria by enzyme-linked immunosorbent assay using spectrophotometry (reagents from ORGenTec, Germany). Regulatory values of microalbumin in the set of reagents used $-0-25 \mu \mathrm{g} / \mathrm{ml}$.

Venous blood samples were taken from subjects on an empty stomach in the morning (up to $9 \mathrm{am}$ ) after 10-12 hours of fasting.

Blood glucose was determined by enzymatic, ampermetric method on a biochemical analyzer Biosen C_Line, manufacturer EKF Diagnostic (Germany). Glucose content was determined using special sensor chips. When the sample is applied to the chip sensors, $\beta$-D-glucose is converted enzymatically by glucose oxidase into gluconic acid and hydrogen peroxide, which reacts with the electrode. The measurement result was an electric current that is proportional to the glucose concentration. Reference norms of blood glucose 3.3-5.5 mmol/l. Blood glucose levels were determined on an empty stomach and 2 hours after a meal, after which its average value was calculated.

Creatinine was determined spectrophotometrically using picric acid on a biochemical analyzer using standard kits from Pointe Scientific (USA). The method of determining creatinine is kinetic colorimetric using picric acid. Regulatory values of this indicator are $0.035-0.124 \mathrm{mmol} / \mathrm{l}$; 35.36 $123.76 \mu \mathrm{mol} / \mathrm{l}$.

The level of cystatin $C$ was determined by enzymelinked immunosorbent assay (ELISA) using the kit RD191009100 Human Cystatin C ELISA company BioVendor (Czech Republic). Regulatory values for cystatin $\mathrm{C}$ are $0.57-1.12 \mathrm{mg} / \mathrm{l}$ for women and $0.6-1.11 \mathrm{mg} / \mathrm{l}$ for men.

GFR levels $\left(\mathrm{ml} / \mathrm{min} / 1.73 \mathrm{~m}^{2}\right)$ were calculated for creatinine (Cockcroft-Gault formula and CKD EPI) and cystatin $\mathrm{C}$.

The formula for calculating GFR according to Cockcroft-
Gault:

GFR (for men) $=((140-$ age $x$ body weight $) /$ blood creatinine) $\times 1.23$

GFR (for women) $=((140-$ age $x$ body weight $) /$ blood creatinine) $\times 1.05$;

where, age - in years; body weight - in kg; blood creatinine - $\mu \mathrm{mol} / \mathrm{l}$.

The calculation of GFR by CKD-EPI was performed using an online calculator.

The formula for calculating GFR on cystatin C:

GFR $=100 /$ cystatin C -14 .

Correlation analysis between sets of indicators was calculated using Spearman statistics in the license package "Statistica 5.5".

\section{Results. Discussion}

Urinary albumin levels in the general group of patients and in men with normoalbuminuria were found to have significant (weak and moderate) direct $(r=0.23$ and $r=0.47)$ correlations with GFR by Cockcroft-Gault; in the general group of patients and in men with microalbuminuria, significant mean feedback $(r=-0.31$ to -0.49$)$ correlations with GFR by Cockcroft-Gault and EPI.

Creatinine levels in the general group of patients, men and women with normoalbuminuria have significant strong feedback ( $r=-0.73$ to -0.96$)$ correlations with GFR by Cockcroft-Gault and EPI; in the general group of patients, in men and women with microalbuminuria has significant strong feedback ( $r=$ from -0.63 and $r=-0.95$ ) correlations with GFR by Cockcroft-Gault and EPI; in the general group of patients, men and women with proteinuria has significant strong feedback ( $r=$ from -0.82 to -0.99 ) correlations with GFR by Cockcroft-Gault and EPI.

The level of cystatin $C$ in the general group of patients, men and women with normoalbuminuria and cystatin $\mathrm{C}<0.9$ and $>0.9$ has significant strong feedback $(r=-1.0$ in all cases); in the general group of patients, in men and women with microalbuminuria and cystatin $\mathrm{C}<0.9$ and $>$ 0.9 has significant strong feedback ( $r=-1.0$ in all cases); in the general group of patients and in men with proteinuria and cystatin $\mathrm{C}<0.9$ and in women with cystatin $\mathrm{C}>0.9$ has significant strong feedback ( $r=-1.0$ in all cases) with GFR on cystatin $\mathrm{C}$.

The mean level of blood glucose in the general group of patients with microalbuminuria has a significant weak direct ( $r=0.29$ ) correlations with GFR by Cockcroft-Gault; in the general group of patients and in women with proteinuria has significant strong feedback $(r=-0.52$ and up to -0.90$)$ correlations with GFR by Cockcroft-Gault and EPI.

The mean level of blood glucose in the general group of patients and in women with proteinuria has significant strong direct $(r=0.62$ and $r=0.91)$ correlations with creatinine levels.

There were no significant associations between cystatin C levels $<0.9$ and $>0.9$ between the mean blood glucose level in the general group of patients and men, in women 
with normo-, microalbuminuria and proteinuria.

Creatinine levels in men with microalbuminuria have a significant mean feedback $(r=-0.46)$ correlation with cystatin $\mathrm{C}$ levels.

Creatinine levels in the general group of patients with normoalbuminuria and cystatin $\mathrm{C}>0.9$ have a significant mean feedback $(r=-0.37)$; in the general group of patients and in men with proteinuria and cystatin $\mathrm{C}<0.9$ has significant strong feedback $(r=-0.90$ and $r=-0.88)$ correlations with the level of cystatin $\mathrm{C}$.

An important clinical and diagnostic aspect is the assessment of the risk of progression of kidney damage. In diabetic nephropathy, all cellular elements of the kidney (glomerular endothelium, podocytes, mesangiocytes, tubular epithelium) are damaged. Defeat of glomeruli as a result leads to increased penetration of plasma proteins (albumin, transferrin) and increased synthesis of extracellular matrix proteins [18].

GFR is the number of nephrons multiplied by the GFR of the middle single nephron (SN-GFR) and the decrease in the number of nephrons due to kidney damage can be compensated by an increase in surviving nephrons (renal functional reserve). Only when all surviving nephrons reach their maximum ability to filter, their further loss leads to a decrease in GFR and the relationship between GFR and kidney damage becomes linear [3, 4].

That is why there was a change in the direction of correlations of urinary albumin levels in the general group of patients and men: in normoalbuminuria positive $(r=0.23$ and $r=0.47$ ) with GFR by Cockcroft-Gault, and in microalbuminuria - inverse ( $r=$ from -0.31 to -0.49$)$ with GFR by Cockcroft-Gault and EPI.

Until recently, albuminuria was considered the earliest manifestation of the onset of diabetic nephropathy. Thus, with a decrease in the degree of FR in $20-40 \%$ of patients with diabetes progresses albuminuria and nephropathy. However, according to the results of modern research, it has become known about the pathological changes that long preceded the onset of albuminuria. In patients with re-diagnosed T1D, GFR begins to decline before albuminuria [5, 17].

Given the lack of significant correlations in normoalbuminuria between urinary albumin and GFR by Cockcroft-Gault (in women), CKD EPI and cystatin C (in all study groups), it can be assumed that this indicator is characterized by insufficient sensitivity and specificity to detect "early" and preclinical stages of diabetic nephropathy. The rank correlation analysis did not reveal significant relationships between urinary albumin levels and GFR by Cockcroft-Gault, CKD EPI and cystatin $C$ in the proteinuria group, which does not allow to consider microalbuminuria as an independent predictive marker of late stages of DN.

The tubular-interstitial department plays an important role in the pathogenesis of diabetic nephropathy. Proximal tubules are particularly sensitive to the effects of metabolic and hemodynamic disorders. In T1D, hyperglycemia initiates disruption of various metabolic pathways, which leads to the accumulation of extracellular matrix components and fibrosis, and thus to a decrease in the number of nephrons and deterioration of renal function [1].

The correlation analysis in the general group and in women with proteinuria revealed an association between the mean blood glucose and low GFR by Cockcroft-Gault, CKD EPI (negative mean correlation $r=$ from -0.31 to -0.46 ) and elevated creatinine (positive strong correlation $r=0.62$ and $r=0.91$ ), indicating an adverse role of hyperglycemia in the development of nephropathy in patients with T1D.

Correlations of cystatin $\mathrm{C}$ concentration with the average value of glucose (direct: weak in the general group and in women with normoalbuminuria and different levels of cystatin $\mathrm{C}$; medium strength and strong in the group in the general group and in men with microalbuminuria and cystatin $\mathrm{C}$ level $<0.9$; in women with proteinuria and cystatin $\mathrm{C}>0.9$, and reverse: weak and moderate in the general group and in men with microalbuminuria and cystatin $\mathrm{C}>0.9$, medium in the general group and in men with proteinuria and cystatin $\mathrm{C}<0.9$ and in men with cystatin level $\mathrm{C}>0.9$ ) did not reach the degree of statistical significance.

The correlation analysis showed higher correlations between the level of cystatin C and GFR by cystatin $C$ ( $r=-$ 1.0) than the level of creatinine with GFR by Cockcroft-Gault ( $r=$ from -0.63 to 0.99$)$ and by CKD EPI ( $r=$ from -0.73 to 0.99). The strength of the correlations increases from GFR by Cockcroft-Gault to GFR by cystatin C. This leads to the conclusion that cystatin $\mathrm{C}$ is more than creatinine, close to the values of GFR determined by endogenous markers ("gold standard") [7].

Correlations of creatinine with GFR by Cockcroft-Gault and CKD EPI were characterized by sex differences (greater values in women) and an increase in their strength synchronously with an increase in the level of microalbumin in the urine. At the same time, there is a consistently high identical value $(r=-1.0)$ of correlations of the level of cystatin $C$ with GFR on cystatin $C$ in all comparison groups. Neither the sex factor nor the degree of albuminuria affected the change in their strength. This means that the formula for determining GFR by cystatin $C$ gives more reliable results than GFR calculated on creatinine and works in the socalled "blind zone" of creatinine, regardless of the sex factor [12].

Only men with microalbuminuria had moderate feedback between creatinine and cystatin $C(r=-0.46)$. In all groups of women, in the general group and in men with normoalbuminuria and proteinuria, the correlations are close to zero, which may indicate the absence of a linear relationship between these indicators. When dividing the sample by cystatin $C$ level between creatinine level and cystatin $\mathrm{C}$ level, the following were found: medium feedback $(r=-0.37)$ in the general group with normoalbuminuria and cystatin $\mathrm{C}>0.9$; moderate feedback $(r=-0.37)$ in the general group and in men with proteinuria and cystatin $\mathrm{C}<0.9$ strong 
feedback $(r=-0.90$ and $r=-0.88)$.

In previous publications [13-16] it was found that in patients with T1D renal dysfunction in the early stages is manifested by impaired filtration function, characterized by increased serum levels of cystatin C and, accordingly, a decrease in GFR by cystatin C, and at later stages - a decrease in GFR, calculated on creatinine (by CockcroftGault and CKD EPI), increase in urinary albumin, albumincreatinine ratio and serum creatinine. Accordingly, the assessment of the rate of change of glomerular filtration and its correlation analysis with classical markers of renal pathology made it possible to detail the diagnosis in patients with T1D at different stages of DN.

Thus, in the course of correlation analysis it was established:

microalbuminuria is not an independent marker of DN, starting from preclinical and ending with the clinically manifested stage of this complication;

for timely and adequate diagnosis of DN it is necessary to measure the level of albumin, creatinine and cystatin C, which are independent markers of renal dysfunction;

cystatin $\mathrm{C}$ gives a more accurate approximation to the actual values of GFR than creatinine;

\section{References}

[1] Alicic, R. Z., Rooney, M. T., \& Tuttle, K. R. (2017). Diabetic kidney disease: challenges, progress, and possibilities. Clinical Journal of the American Society of Nephrology, 12(12), 20322045. doi: $10.2215 / C J N .11491116$

[2] Alicic, R. Z., Rooney, M. T., \& Tuttle, K. R. (2017). Diabetic kidney disease: challenges, progress, and possibilities. Clinical Journal of the American Society of Nephrology, 12(12), 20322045. doi: 10.2215/CJN.11491116

[3] Anders, H. J., Huber, T. B., Isermann, B., \& Schiffer, M. (2018). CKD in diabetes: diabetic kidney disease versus nondiabetic kidney disease. Nature Reviews Nephrology, 14(6), 361-377. doi: 10.1038/s4158 1-018-0001-y

[4] Anguiano G?mez, L., Lei, Y., Kumar Devarapu, S., \& Anders, H. J. (2018). The diabetes pandemic suggests unmet needs for "CKD with diabetes" in addition to "diabetic nephropathy" implications for pre-clinical research and drug testing. Nephrology Dialysis Transplantation, 33(8), 1292-1304. doi: $10.1093 / \mathrm{ndt} / \mathrm{gfx} 219$

[5] Argyropoulos, C., Wang, K., Bernardo, J., Ellis, D., Orchard, T., Galas, D., \& Johnson, J. P. (2015). Urinary microRNA profiling predicts the development of microalbuminuria in patients with type 1 diabetes. Journal of Clinical Medicine, 4(7), 14981517. doi: $10.3390 / \mathrm{jcm} 4071498$

[6] Barr, A. J. (2018). The biochemical basis of disease. Essays in biochemistry, 62(5), 619-642. doi: 10.1042/EBC20170054

[7] Bjornstad, P., Karger, A. B., \& Maahs, D. M. (2018). Measured GFR in routine clinical practice - the promise of dried blood spots. Advances in chronic kidney disease, 25(1), 76-83. doi: 10.1053/j.ackd.2017.09.003

[8] Cadegiani, F. A., \& Kater, C. E. (2019). Inter-correlations among clinical, metabolic, and biochemical parameters and their predictive value in healthy and overtrained male athletes: the eros-correlations study. Frontiers in endocrinology, 10, 858. doi: 10.3389 /fendo.2019.00858

[9] Charlton, A., Garzarella, J., Jandeleit-Dahm, K. A., \& Jha, J. C. (2021). Oxidative Stress and Inflammation in Renal and Cardiovascular Complications of Diabetes. Biology, 10(1), 18. cystatin $\mathrm{C}$ is more sensitive in the early stages, and creatinine is a marker of later stages of DN development;

hyperglycemia - is the main initiating metabolic factor in the development and progression of DN.

\section{Conclusions and prospects for further development}

1. Correlation analysis allowed to establish inverse relationships between serum cystatin $C$, creatinine and glucose levels with renal function (GFR by Cockcroft-Gault, CKD EPI or cystatin C), and also demonstrated that cystatin $C$ can be an informative and accurate method for determination of renal function, an early marker of the severity of renal complications in patients with T1D.

In further research it is planned to develop a discriminant model of the possibility of $\mathrm{T} 1 \mathrm{D}$ at the stage of normoalbuminuria, taking into account the level of cystatin $\mathrm{C}$ depending on clinical, laboratory and anthropometric parameters, which can be used for in-depth understanding of the most significant pathological processes in patients with T1D and will allow to begin their prevention and treatment at an earlier date.

[10] Chekman, I. S., Trachtenberg, I. M., Belenichev, I. F., Buhtiyarova, N. V., Gorchakova, N. A., \& Levich, S. V. (2017). Some aspects of in vitro studies of neurotoxicity: from choice of biochemical and molecular markers to the confirmation of their informativity. Biological Markers and Guided Therapy, 4(1), 71-90. doi: 10.12988/bmgt.2017.758

[11] Hayashi, Y. (2019). Detection of lower albuminuria levels and early development of diabetic kidney disease using an artificial intelligence-based rule extraction approach. Diagnostics, 9(4), 133. doi: $10.3390 /$ diagnostics 9040133

[12] Krishnamurthy, N. (2017). Creatinine blind area vs. cystatin C blind area in patients with chronic kidney diseases. Biochem Anal Biochem, 6(3), 54. doi: 10.4172/2161-1009-C1-015

[13] Kryvoviaz, Yu. O. (2020). General clinical and anthropometric parameters in patients with type 1 diabetes mellitus depending on the level of albumin in the urine. Biomedical and Biosocial Anthropology, 38, 61-68. doi: 10.31393/bba38-2020-09

[14] Kryvoviaz, Yu. O., Shevchuk, N. A., Dzevulska, I. V., Bandurka, N. M., \& Shevchuk Yu. G. (2021). Features of lipid, carbohydrate metabolism and renal function in patients with type 1 diabetes and different levels of albumin in the urine depending on the level of cystatin C. Вісник Вінницького національного медичного університету - Reports of Vinnytsia National Medical University, 25(1), 50-56. doi: 10.31393/reportsvnmedical-2021-25(1)-09

[15] Kryvoviaz, Yu. O., Vernigorodskiy, V. S., Adarsh Kumar, Dzevulska, I. V., \& Kyrychenko, V. I. (2020). Features of biochemical parameters in healthy and patients with type 1 diabetes mellitus with different levels of albumin in the urine. Biomedical and Biosocial Anthropology, 39, 23-28. doi: 10.31393/bba39-2020-04

[16] Kryvoviaz, Yu. O., Vernigorodskiy, V. S., Dzevulska, I. V., Shevchuk, Yu. G., \& Zhuchenko, P. S. (2020). Features of the frequency of angio-, retino- and neuropathy, general clinical and anthropometric parameters in patients with type 1 diabetes with different levels of albumin in the urine depending on the level of cystatin C. Вісник морфології - Reports of Morphology 
26(3), 14-23. doi: 10.31393/morphology-journal-2020-26(3)02

[17] Maclsaac, R. J., Ekinci, E. I., \& Jerums, G. (2014). Progressive diabetic nephropathy. How useful is microalbuminuria?: contra. Kidney international, 86(1), 50-57. doi: 10.1038/ki.2014.98
[18] Reidy, K., Kang, H. M., Hostetter, T., \& Susztak, K. (2014). Molecular mechanisms of diabetic kidney disease. The Journal of clinical investigation, 124(6), 2333-2340. doi: 10.1172/ JCl72271

\section{ОСОБЛИВОСТІ ЗВ'ЯЗКІВ БІОХІМІЧНИХ ПОКАЗНИКІВ ІЗ ШВИДКІСТЮ КЛУБОЧКОВОЇ ФІЛЬТРАЦІЇ ЗА КОКРОФТОМ- ГОЛТОМ, СКD ЕРІ ТА ЗА ЦИСТАТИНОМ С У ХВОРИХ НА ЦУКРОВИЙ ДІАБЕТ 1 ТИПУ}

\section{Кривов'яз Ю}

Анотація. Мета дослідження - вивчити особливості кореляцій біохімічних показників із швидкістю клубочкової фрільтрації за Кокрофтоом-Голтом, CKD EPI та за цистатином С у хворих на иукровий діабет 1 типу (ЦД 1). Обстежено 78 чоловіків $i$ 62 жінок віком 22-26 років, хворих на ЦД 1. Контрольна група складалась з 8 практично здорових чоловіків і 13 практично здорових жінок аналогічного віку. Усім пацієнтам імунофрерментним методом визначали рівень мікроальбумінурії та цистатину С. Проводилась біохімічна оцінка глюкози крові натще, глюкози через 2 год після навантаження, середнього значення глюкози, креатиніну, ШКФ за Кокрофотом-Голтом, ШКФ за СKD EPI та ШКФ за иистатином С. Кореляційний аналіз між рядами показників розраховували за допомогою статистики Spearman в ліцензійному пакеті "Statistica 5.5". У хворих на ЦД1 відмічається відсутність достовірних кореляцій при нормоальбумінурії між рівнем альбуміну в сечі та ШКФ за КокрофртомГолтом (у жінок), CKD EPI і за иистатином C (в усіх групах дослідження). Не виявлено достовірних взаємозв'язків між рівнем альбуміну в сечі і ШКФ за Кокрофотом-Голтом, CKD EPI і за цистатином С в групі протеїнурії. Проведений кореляційний аналіз виявив у загальної групи і у жінок з протеїнурією асоціацію між середнім значенням глюкози крові та зниженим рівнем ШКФ за Кокрофтоом-Голтом, за CKD EPI (негативний середньої сили зв'язок $r=$ від -0,31 до -0,46) та підвищеним вмістом креатиніну (позитивний сильний зв'язок $r=0,62$ i $r=0,91$ ), що свідчить про несприятливу роль гіперглікемії в розвитку нефропатії у пацієнтів з ЦД1. Продемонстровано більш високі кореляції рівня цистатину С з ШКФ за цистатином $C$ ( $r=-$ 1,0), ніж рівня креатиніну з ШКФ за Кокрофотом-Голтом ( $r=$ від - 0,63 до 0,99) та за CKD EPI (r= від -0,73 до -0,99). Сила кореляцій зростає від ШКФ за Кокрофртом до ШКФ за цистатином С. Кореляціям рівня креатиніну з ШКФ за КокрофртомГолтом та за CKD EPI були притаманні гендерні відмінності (більші значення у жінок) та зростання їх сили синхронно зі зростанням рівня мікроальбуміну в сечі. В той же час, відмічається стабільно високе ідентичне значення $(r=-1,0)$ кореляцій рівня цистатину $C$ з ШКФ за цистатином $C$ в усіх групах порівняння. Ні фрактор статі, ні ступінь альбумінурії не вплинули на зміну їх сили. Лише у чоловіків з мікроальбумінурією між рівнем креатиніну та рівнем цистатину $C$ встановлено середньої сили зворотній зв'язок $(r=-0,46)$. В усіх групах жінок, у загальній групі $і$ у чоловіків з нормоальбумінурією $і$ протеїнурією кореляції наближені до нуля, що може свідчити за відсутність лінійного взаємозв'язку між зазначеними показниками. При поділі вибірки за рівнем иистатину $C$ між рівнем креатиніну та рівнем иистатину $C$ встановлені: середньої сили зворотній зв'язок $(r=-0,37)$ в загальній групі з нормоальбумінурією і цистатином C>0,9; середньої сили зворотній зв'язок $(r=-0,37)$ в загальній групі і у чоловіків з протеїнурією і цистатином $C<0,9$ зворотні сильні зв'язки ( $r=-0,90$ і $r=-0,88)$. Таким чином, в ході кореляційного аналізу встановлено: мікроальбумінурія не є самостійним маркером діабетичної нефропатії (ДН), починаючи від доклінічної і завершуючи клінічно-маніфестованою стадією даного ускладнення; для своєчасної та адекватної діагностики ДН необхідне вимірювання рівня альбуміну, креатиніну і цистатину С, які є незалежними один від одного маркерами порушення фрункції нирок; цистатин $C$ дає більш точне наближення до реальних значень ШКФ, ніж креатинін; цистатин $C \epsilon$ більш чутливим на ранніх стадіях, а креатинін $є$ маркером більш пізніх стадій розвитку ДН; гіперглікемія - $\epsilon$ основним ініціюючим метаболічним фрактором розвитку і прогресування ДН.

Ключові слова: иукровий діабет 1 типу, рівень цистатину C, рівень альбуміну в сечі, біохімічні показники, ШКФ за Кокрофртом-Голтом, СKD EPI та за цистатином С, кореляції. 